\title{
PENINGKATAN PEMAHAMAN TERHADAP KAMPUNG TEMATIK MASYARAKAT RT 01 DAN RT 02 KELURAHAN PANUNGGANGAN UTARA
}

\author{
Marchelia Gupita Sari $^{1}$, Imaniar Sofia Asharhani ${ }^{1}$, Anisza Ratnasari ${ }^{1}$ \\ ${ }^{1}$ Program Studi Arsitektur, Universitas Pradita \\ marchelia.gupita@pradita.ac.id,imaniar.sofia@pradita.ac.id, anisza.ratnasari@pradita.ac.id
}

\begin{abstract}
Abstrak
Program Kampung Tematik di Kota Tangerang nampaknya didaulat oleh pemerintah kota sebagai upaya untuk meningkatkan kesejahteraan masyarakat. Peran aktif masyarakat sangat diperlukan dalama pembangunan lingkungan tempat bermukim. Begitu pula dalam menentukan konten atau tema dalam perencanaan Kampung Tematik agar tepat sasaran. Masyarakat diharapkan dapat menjadi subjek pembangunan, bukanlah hanya sebagai penerima kebijakan semata karena berdampak pada kesehariannya. Di satu sisi, potensi masyarakat dan alam, baik tangible maupun intagible, dan aspirasi masyarakat semestinya dapat digali sebagai dasar penentuan tema. Universitas Pradita sebagai perguruan tinggi dalam lingkup skala provinsi Banten mendampingi masyarakat Kelurahan Panunggangan Utara sebagai wujud pelaksanaan Tridharma. Dalam langkah-langkah perencanaan Kampung Tematik oleh Pemerintah Kota Tangerang, langkah pencarian ide, yaitu pendataan atau dokumentasi, pemetaan, dan sosialisasi mengenai Kampung Tematik. Peningkatan Pemahaman ini menjadi langkah awal yang penting mengingat belum ditemukan kegiatan serupa di lokus kegiatan, padahal masyarakat membutuhkannya supaya pengembangan Kampung Tematik lebih terarah. Pada hasil pre-test dan post-test didapatkan bahwa adanya peningkatan pemahaman setelah sosialisasi dilakukan. Diskusi terjalin dengan baik terbukti dari jawaban warga terhadap pertanyaan tentang pendapat mereka akan keinginan dan kesadaran terhadap potensi area tersebut untuk dikembangkan menjadi kampung wisata.
\end{abstract}

Kata kunci : kampung wisata tematik, Panunggangan Utara, partisipasi masyarakat,

\section{PENDAHULUAN}

Panunggangan Utara adalah kelurahan yang berada di kecamatan Pinang, Kota Tangerang, Banten, Indonesia. Kelurahan ini terdiri atas 41 (empat puluh satu) rukun tetangga (RT) dan 5 (lima) rukun warga (RW). Luas Kelurahan Panunggangan Utara adalah $1.8 \mathrm{~km}^{2}$ dengan jumlah penduduk kurang lebih 17.916 jiwa, dan kepadatan $9.953 \mathrm{jiwa} / \mathrm{km}^{2}$.

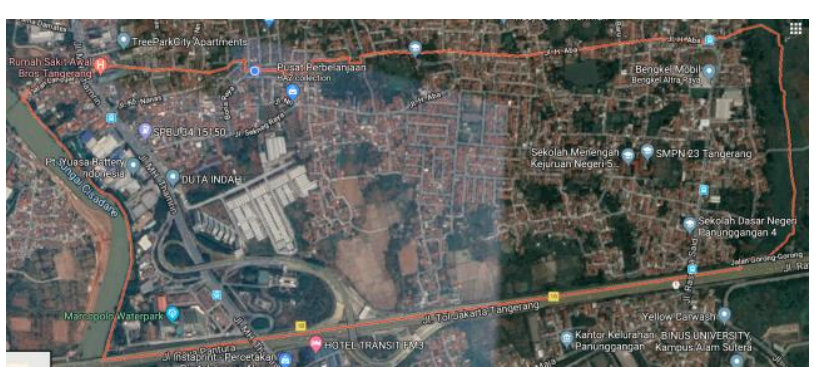

Ekonomi, Sosial, dan Budaya 


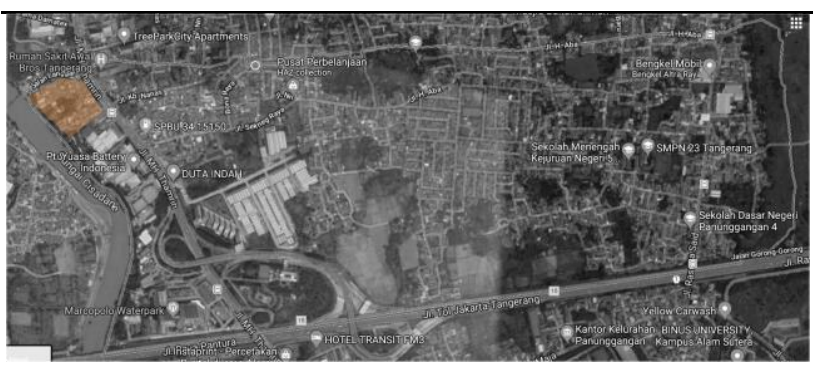

Gambar 1. Lokasi kegiatan Pengabdian kepada Masyarakat

Literatur mengenai Kelurahan Panunggangan Utara sebagai lokasi kegiatan Pengabdian kepada Masyarakat atau penelitian dengan tema Partisipasi Masyarakat belum banyak ditemukan padahal lokasi kelurahan ini terbilang strategis karena dekat dengan Sungai Cisadane sebagai salah satu identitas Kota Tangerang. Selain itu, menurut key person dari Kelurahan Panunggangan Utara, terdapat potensi industri rumahan yang dapat dikembangkan sebagai tema Kampung Tematik. Di sisi lain, Pemerintah Kota Tangerang kini sedang menggalakkan Program Kampung Tematik sebagai usaha untuk peningkatan kesejahteraan masyarakat.

Pemerintah Kota Tangerang memiliki program memiliki destinasi wisata kampung tematik sebagai salah satu upaya untuk pengentasan kemiskinan, seperti yang dilansir pada paparan Pembentukan Kampung Tematik Kota Tangerang oleh Pemerintah Kota Tangerang Untuk mendukung program tersebut, Pemerintah Kota Tangerang telah mencetuskan adanya Unsur-unsur pendamping, yaitu sebagai berikut : Inovator dan Motivator, Lembaga Swadaya Masyarakat (LSM), Perguruan Tinggi, dan Pemerintah Kota / Daerah. Universitas Pradita sebagai salah satu perguruan tinggi yang berada di lingkup Provinsi Banten diharapkan turut memberikan kontribusi terhadap program ini dalam fungsi Tridarmanya.

Pembentukan Kampung Tematik merupakan program pemerintah yang menarik di mana tahap awal pelaksanaan menjadi hal yang krusial karena harus melihat potensi wilayah perencanaan. Oleh karena itu, keterlibatan masyarakat diperlukan. Keterlibatan masyarakat dalam tahap perencanaan adalah masyarakat dilibatkan dalam mengidentifikasi masalah, penentuan tujuan dan pengambilan keputusan terkait pengembangan kawasan (Dewi, Fandeli, \& Baiquni, 2013).

\section{Desain Partisipatif}

Dalam perwujudan pengembangan kawasan, dilakukan beberapa pendekatan, yaitu top down approach dan bottom up approach. Pendekatan yang mengutamakan kebutuhan dan aspirasi dari bawah, lalu mewujudkannya sebagai program yang dibentuk ke atas disebut bottom up approach sedangkan ketika keinginan merencanakan ruang di ranah publik dikuasai dan ditentukan oleh penguasa dengan menitikberatkan pada stabilitas, pertumbuhan, dan pemerataan disebut dengan top down approach. Menurut Simmel et.al, kedua pendekatan ini memerlukan 4 (empat) hal yang saling mendukung, yaitu : momentum, pelaksanaan dan penyesuaian rencana serta menciptakan dukungan masyarakat. Aksi partisipatif dari masyarakat dapat ditumbuhkan dari rasa solidaritas, maupun kesadaran individu yang kreatif.

Desain partisipatif merupakan perancangan yang secara aktif diikuti oleh para pemangku kepentingan pada proses dan prosedurnya. Pemangku kepentingan yang terlibat adalah pengguna akan datang (future user) yang merupakan penduduk sekitar lokasi. Desain partisipatif didasari oleh kondisi ideal demokrasi dengan penarikan keputusan yang memiliki efek pada pengguna. Penarikan keputusan dalam perancangan merupakan hal yang kompleks, perlu adanya informasi dan verifikasi dari masyarakat.

\section{Focus Group Discussion}

Focus Group Discussion (FGD) jika diterjemahkan dalam Bahasa Indonesia adalah proses diskusi terarah. Focus group discussion adalah suatu proses pengumpulan data dan informasi yang sistematis mengenai suatu permasalahan tertenu yang sangat spesifik melalui diskusi kelompok. Berbeda dengan wawancara, dalam FGD moderator bukan untuk bertanya, tetapi mengungkapkan suatu persoalan yang akan menjadi bahan diskusi. Menurut Manderson dan Tallo (1993) jumlah ideal untuk dilakukannya FGD adalah sekitar 7-15 orang.

Dalam proses Focus Group Discussion, diperlukan peran-peran berikut ini,

1. Moderator, sebagai fasilitator diskusi yang memahami masalah; 
2. Pencatat proses, sebagai orang yang mengikuti dan mencatat proses diskusi dan sebagai pembantu moderator;

3. Penghubung peserta, sebagai orang yang menghubungi dan memastikan partisipasi peserta;

4. Blocker, sebagai orang yang menghalau pengaruh-pengaruh negatif dalam pelaksaan FGD;

5. Logistik, sebagai orang yang menyiapkan kebutuhan peserta

\section{METODE}

Pada tahap persiapan, dilakukan survei dilakukan untuk pemetaan sosial secara skematis dan sederhana. Pemetaan Sosial adalah satu metode visual yang menunjukkan lokasi relatif suatu komunitas atau kelompok yang dilakukan untuk menemukenali dan mendalami kondisi sosial komunitas tersebut. Pemetaan sosial dilangsungkan secara singkat dan cepat tentang kondisi sosial masyarakat di sekitar lokasi yang diusulkan sebagai lokasi perencanaan.

Pemetaan sosial secara sederhana dilakukan untuk mengindentifikasi individu dan kelompok utama yang penting untuk dilibatkan dalam perancangan, mengidentifikasi kegiatan yang ada dalam kegiatan masyarkat, mengidentifikasi kegiatan yang diharapkan terjadi, dan mengidentifikasi potensi masalah dan solusinya. Pada tahap ini luaran yang dihasilkan adalah datadata berupa peta dan informasi bersifat deskriptif kualitatif.

Setelah itu, pada tanggal 5 Agustus 2021 (terlampir) tim PKM mengadakan Gladi Bersih pelaksanaan acara secara daring karena adanya PPKM (Pemberlakukan Pembatasan Kegiatan Masyarakat) Level 4 sejak Sabtu, 3 Juli 2021 akibat kondisi terkini pandemi COVID-19. Oleh karena itu, acara akan dilaksanakan secara daring menyeluruh. Koordinasi dilakukan oleh pelaksana kepada Ketua RT sebagai key person agar warga dapat mengunduh platform daring.

Tahap pelaksanaan dibagi menjadi Focus Group Discussion (FGD) bersama masyarakat
Kelurahan Panunggangan Utara dan Pembuatan Road Map Kampung Wisata oleh tim Pengabdian kepada Masyarakat. Untuk kegiatan Focus Group Discussion, terbagi menjadi 2 (dua) sesi, yaitu : pemaparan atau Sosialisasi konsep - konsep Kampung Tematik oleh Tim Pengabdian kepada Masyarakat sehingga warga mendapatkan pengetahuan tentang Kampung atau Desa Tematik secara umum agar diskusi dapat terjalin lebih terstruktur. Setelah itu, diadakan diskusi bersama mengenai aspirasi masyarakat.

Aspirasi masyarakat mengenai tema Kampung Wisata yang akan diimplementasikan ke Kelurahan Panunggangan Utara. Mendapatkan gambaran potensi masyarakat berupa produk yang berpotensi untuk diunggulkan, kegiatan-kegiatan komunitas, dan tempat-tempat yang memiliki nilai berdasarkan persepsi masyarakat setempat.

\section{HASIL DAN PEMBAHASAN}

\section{Pre-Test}

Pelaksana kegiatan PKM membagikan formulir pendaftaran berupa Google Form kepada warga RT 01 dan RT 02 untuk diisi. Formulir tersebut sekaligus menjadi pre-test untuk mengetahui seberapa jauh warga memiliki pemahaman terhadap Kampung Tematik, Kampung Wisata, dan konsep Kampung Mengalir yang telah digaungkan oleh pihak kelurahan Panunggangan Utara berdasarkan korespondensi selama April 2021 hingga Juni 2021. Pengisian Google Form Pre-Test berlangsung cukup lancar dengan adanya submission jawaban dari warga. Tinjauan analisis terhadap pre-test akan dibahas pada bab 5.2. Contoh dari Pre-Test di bawah ini: 


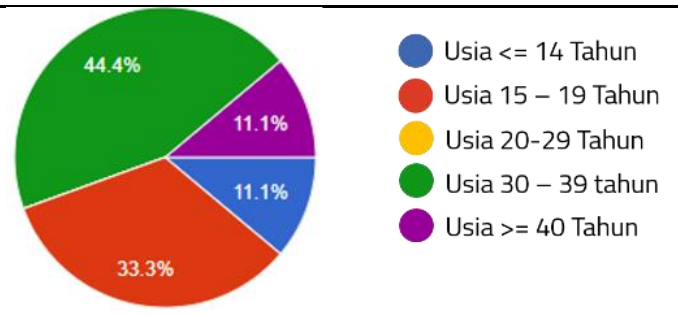

Gambar 2. Pre-Test dari Google Form Pendaftaran Peserta yang tidak beragam

Kegiatan Sosialisasi telah terlaksana pada hari Sabtu, 7 Agustus 2021 pukul 15.00 - 16.30 WIB secara daring karena adanya kondisi terkini, yaitu PPKM (Pemberlakuan Pembatasan Kegiatan Masyarakat) oleh pemerintah. Adapun improvisasi yang dilakukan dalam kegiatan daring ini adalah koordinator pelaksana PKM, Marchelia Gupita Sari, mengadakan pertemuan terbatas pada tanggal 7 Agustus 2021 pukul 14.00 WIB hingga 14.30 WIB dengan perwakilan warga yang ternyata mengalami kesulitan teknis dalam penggunaan online meeting. Adapun kesulitan yang ditemukan adalah warga kurang familiar dengan platform Google Meet. Pertemuan terbatas tersebut berlangsung di Balai Warga RT 01 dan RT 02, RW 01 Panunggangan Utara. Pertemuan tersebut menerapkan protokol kesehatan ketat, yakni memakai masker dan menjaga jarak.

Agenda yang dilakukan sebelum dimulainya acara online adalah tutorial singkat menengenai bagaimana cara berpartisipasi pada online meeting, yaitu mulai dari mengunduh Google Meet hingga memastikan bahwa warga tersebut mampu untuk bergabung dengan satu akun, tidak berkelompok atau berkerumun dengan perangkat bersama. Pertemuan berupa tutorial tersebut hanya dihadiri 5 (lima) warga yang sekiranya membutuhkan bantuan secara bergantian untuk memenuhi physical distancing. Setelah sekiranya dapat bergabung, warga pulang ke rumah masingmasing. Koordinator pelaksana kegiatan berusaha memastikan bahwa warga tidak berkerumun saat acara dimulai.

Tabel 1. Pelaksanaan Jadwal Acara

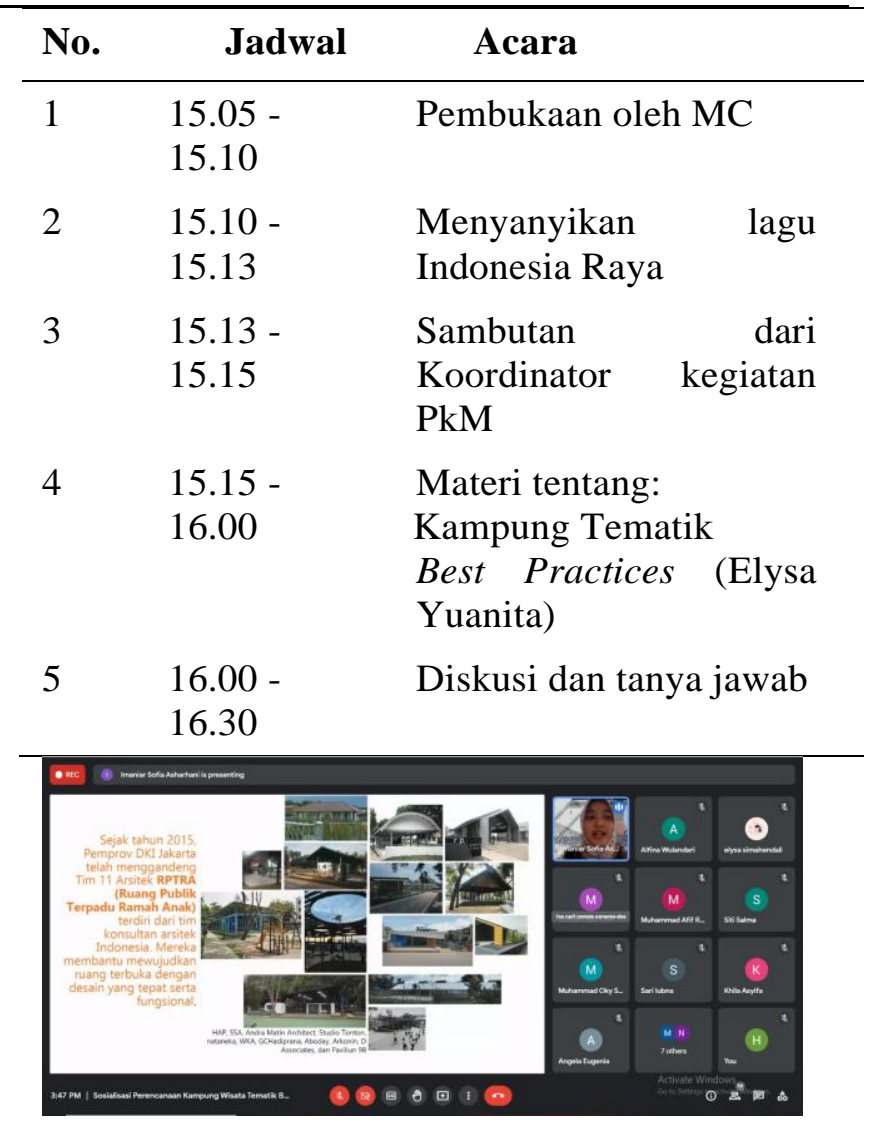

Gambar 3. Dokumentasi pelaksanaan

\section{Post-Test}

Warga yang mengikuti sosialisasi memiliki rentang usia yang tidak terlalu beragam. Sebagian besar yang hadir ialah remaja dengan usia 15-19 tahun serta dewasa usia 30-39 tahun. Hasil pre test ditabulasikan dengan terukur dan diperoleh data $61 \%$ warga tidak mengetahui pengertian dari kampung wisata, dan $76,9 \%$ tidak mengetahui mengenai desain partisipatif. Menurut mereka istilah tersebut jarang terdengar. Sedangkan pengertian kampung mengalir sudah banyak diketahui oleh sebagian besar warga, hanya $23,1 \%$ saja yang tidak mengetahuinya. Sebab adanya informasi tentang Kampung Bekelir di Tangerang memang marak diperbincangkan pada media social, karena diyakini menjadi lokasi yang bagus untuk berfoto. 

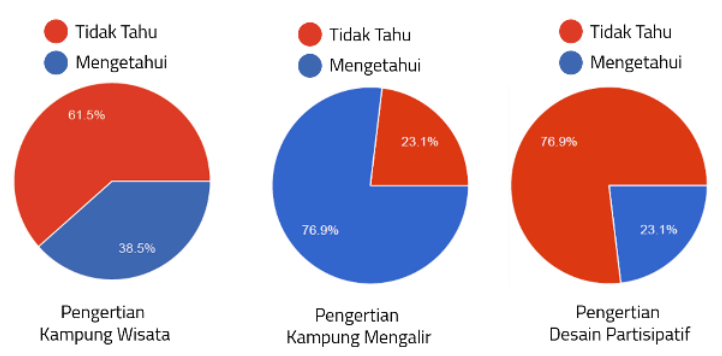

Gambar 4. Post-Test dari Google Form

Dari data tersebut dapat disimpulkan bahwa diperlukan sosialisasi lebih lanjut, misalnya; pemahaman tentang ragam tema untuk peremajaan kampung seperti kampong industri, kampung budaya, kampung baca, hingga kampung KB dan kampong rukun. Selain itu perlu juga diperkenalkan kepada warga RT 01 dan RT 02 untuk menyadari beragam potensi dari area tersebut serta diperihatkan contoh lokasi lain dengan kemiripan potensi telah berhasil menjadi kampong wisata tematik. Hal yang tidak kalah penting ialah perlunya memberikan gambaran mengenai langkah-langkah dalam mewujudkan kampung wisata tematik ialah dengan pendekatan desain berbasis partisipatif.

Pada pelaksanaan kegiatan sosialisasi, antusiasme para warga dalam pelaksanaan kegiatan ini cukup baik, terbukti dari warga tetap menyimak selama proses sosialisasi kegiatan dari awal hingga akhir. Setelah pemaparan diskusi berlangsung dengan interaktif, mengajukan pertanyaan jika ada penjelasan yang kurang jelas dan memberikan pendapat mengenai potensi daerah mereka. Sebagai tindak lanjut dari pretest, Tim PkM Universitas Pradita juga mengadakan post test untuk para warga yang hadir dengan teknik pengumpulan data wawancara. Hasil post test menunjukkan bahwa seluruh peserta telah mamahami mengenai pengertian kampong wisata. Sementara warga yang memiliki pemahaman terhadap pengertian Kampung mengalir, tetap sama seperti pada saat pre-test. Sedangkan pemahaman warga mengenai pengertian desain partisipatif meningkat jauh, hanya $22,2 \%$ warga yang belum berhasil tersosialisasi mengenai pengertian desain partisipatif.
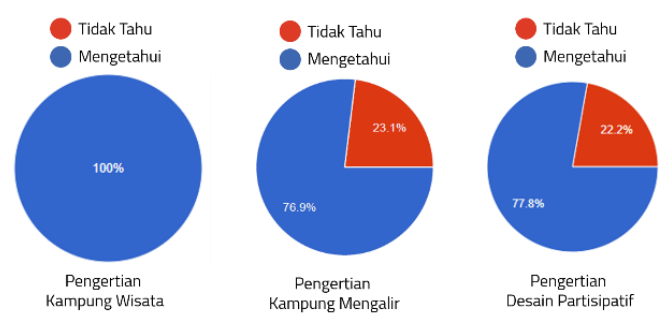

Gambar 5. Post-Test dari Google Form

Hasil wawancara menunjukkan adanya peningkatan pemahaman setelah sosialisasi dilakukan. Diskusi terjalin dengan baik terbuktu dari jawaban warga terhadap pertanyaan tentang pendapat mereka akan keinginan dan kesadaran terhadap potensi area tersebut untuk dikembangkan menjadi kampung wisata. Hasil diskusi menampilkan jawaban dari warga antara lain, yaitu; 1) Menjadikan kampung wisata panunggangan menjadi objek wisata bagi mahasiswi maupun lingkungan luar kelurahan panunggangan Utara, 2) Saya ingin jadikan kampung mengalir lebih banyak manfaat untuk tempat wisata bagi kalangan luas, 3) Saya ingin kampung mengalir ini menjadi taman, untuk wisata yang lebih bagus lagi, 4) Sangat berpotensi untuk dijadikan kampung mengalir, dan dapat memajukan menjadi kampung wisata.

\section{Rencana Keberlanjutan Pelaksanaan Kegiatan PKM \\ Kegiatan PKM ini memiliki kendala dalam} hal ragam peserta yang mengikuti Focus Group Discussion. Peserta ternyata hanya berasal dari Ibu PKK atau Ibu Rumah Tangga dan anak sekolah dan kuliah saja. Hal ini terjadi karena adanya kondisi pandemi terkini yang membuat masyarakat fokus pada sikap terhadap pandemi COVID-19.

Untuk keberlanjutan, perlu untuk dilakukan peningkatan pemahaman terhadap Kampung Tematik, dan dikhususkan lagi untuk Kampung Wisata bagi masyarakat luas, dengan ragam masyarakat yang berbeda.

\section{KESIMPULAN}

Pada hasil pre-test dan post-test didapatkan bahwa adanya peningkatan pemahaman setelah sosialisasi dilakukan. Diskusi terjalin dengan baik terbukti dari jawaban warga terhadap pertanyaan 
tentang pendapat mereka akan keinginan dan kesadaran terhadap potensi area tersebut untuk dikembangkan menjadi kampung wisata.

Namun begitu, perlu dilakukan sosialisasi lanjutan pada masyarakat yang berbeda.

\section{REFERENSI}

Booth, NK. (1983). Basic Elements of Landscape Architecture Design. Illnois.
Dwiluthfianti, Siti Chadijah, Gunawan, Andi.(Desain Partisipatif Pada Taman Lingkungan Permukiman Di Pondok Melati, Bekasi.Skripsi. Institut Pertanian Bogor. Dapat diakses di : https://repository.ipb.ac.id/handle/123456789/79596

Hadi, P. S. (2013). Manusia dan Lingkungan. Semarang: Badan Penerbit Undip.

Sanoff, Henry. 2000. Community Participation Methods in Design and Planning. USA:John Wiley \& Sons, Inc. 